PENGARUH METODE PEMBELAJARAN LEARNING START WITH A

QUESTION (LSQ) TERHADAP HASIL BELAJAR IPS KELAS IV MIN 2 BANDAR LAMPUNG TAHUN PELAJARAN 2017/2018

\author{
MUHAMAD AFANDI \\ Email: muhammadafandi_uin@radenfatah.ac.id \\ ISNAINI NURJANAH \\ Email: Itsnaini.nurjannah@gmail.com \\ DOSEN JURUSAN PGMI UIN RADEN FATTAH PALEMBANG
}

\begin{abstract}
Problems in this research is still low learning result of IPS student of class VI MIN 2 Bandar Lampung. Implementation of learning method of learning with a question (LSQ) aims to determine whether there is influence of Learning start with a question (LSQ) method to the learning result of IPS class IV in MIN 2 Bandar Lampung Lesson year 2017/2018.

Type of research used is Quantitative research with quasy experimental method with nonequivalent control group design design. The location of the research was conducted at MIN 2 Bandar Lampung. Subjects in the study were students grade IV A and IV B MIN 2 Bandar Lampung as many as 69 students. Data collection methods used are Tests and documentation. The data analysis technique used is $t$ test. The test results show the average score of 34 students in the experimental class is 72.35 and in the control class of 35 students the average score is 66,57.

Based on the results of hypothesis testing using Independent t-test obtained that the value of Sig $=0.001$ or tcount $=3.627>$ ttable $=1.997$, This means that the value of tcount is greater than the value of ttable both at the level of 5\%. 10.001 <0.05). So it can be concluded that there is a significant influence on the application of learning learning method with a question to the learning outcomes of IPS students in grade IV MIN 2 Bandar Lampung in the academic year $2017 / 2018$.
\end{abstract}

Keywords: Learning Start With A Question, Learning Outcomes, IPS

\title{
A. PENDAHULUAN
}

Menurut undang-undang No. 20 Tahun 2003 pasal 1 ayat 1 tentang Sistem Pendidikan Nasional dinyatakan, tujuan dari dilaksanakanya pendidikan agar seorang peserta didik mempunyai suatu keterampilan yang dapat mereka gunakan untuk hidup di masyarakat, bangsa dan negara. Salah satu keterampilan yang harus dimiliki peserta didik yaitu keterampilan berinteraksi dengan orang lain. Keterampilan tersebut bisa dipelajari melalui pembelajaran IPS di MI. Pengaruh metode pembelajaran learning start with a question (lsq) terhadap hasil belajar ips kelas iv min 2 bandar lampung tahun pelajaran 2017/2018 
Pembelajaran IPS mengajarkan peserta didik mampu berinteraksi dan berkerja sama dengan teman, sehingga perserta didik mampu menyelesaikan tugas bersama dan hasil yang dicapai akan dirasakan kebaikanya oleh peserta didik itu sendiri yaitu meningkatkan keterampilan berinteraksi dengan orang lain. Untuk itu dalam pelaksanaan pendidikan, peserta didik harus diajarkan Ilmu Pengetahuan Sosial (IPS) sejak dini, karna berfungsi mendidik dan sebagai bekalan bagi peserta didik untuk mampu memecahkan masalah dan berbaur di masyarakat (Susanto, 2014: 45).

Pola pembelajaran IPS di MI hendaknya lebih menekankan pada unsur pendidikan dan pembekalan pemahaman, nilai-moral dan kenterampilanketerampilan sosial pada peserta didik. Untuk itu, penekanan pembelajarannya bukan sebatas pada upaya menjejali peserta didik dengan sejumlah konsep yang bersifat hafalan saja, melainkan terletak pada upaya menjadikan peserta didik memiliki seperangkat pengetahuan, sikap, nilai, dan keterampilan agar mereka mampu menjadikan apa yang telah dipelajarinya sebagai bekal dan memahami dan ikut serta dalam menjalankan kehidupan masyarakat lingkungannya, serta sebagai bekal bagi dirinya untuk melanjutkan pendidikan ke jenjang yang lebih tinggi (Susanto, 2014: 45). Untuk mencapai keberhasilan dalam proses pembelajaran IPS, guru harus dapat mengembangkan segala potensi dan kreativitas peserta didik secara optimal dikarenakan setiap peserta didik mempunyai karakteristik yang berbeda-beda.

Berdasarkan hasil wawancara peneliti dengan guru mata pelajaran IPS di MIN 2 Bandar Lampung, dapat diketahui guru kurang bervariasi dalam penggunaan metode pembelajaran beliau hanya mengunakan metode pembelajaran seperti ceramah, diskusi dan tanya jawab, tetapi mayoritas menggunakan metode ceramah. Berdasarkan observasi yang dilakukan peneliti dengan peserta didik kelas IV di MIN 2 Bandar Lampung, dapat diketahui rendahnya hasil belajar peserta didik terhadap pembelajaran IPS dikarenakan pembelajaran tersebut merupakan materi yang banyak menghafal dan kurangnya kreatifitas guru saat mengajar sehingga hasil belajar peserta didik rendah. Hal tersebut juga merupakan alasan peneliti memilih peseera didik kelas IV sebagai

Pengaruh metode pembelajaran learning start with a question (lsq) terhadap hasil belajar ips kelas iv min 2 bandar lampung tahun pelajaran 2017/2018 
subjek penelitian ini karena ditemukan permasalahan yaitu hasil belajar peserta didik dalam pembelajaran IPS masih rendah.

Pernyataan ini diperkuat dengan data hasil belajar peserta didik yang menunjukkan bahwa data tingkat pemahaman peserta didik terhadap materi masih jauh dari harapan, dilihat dari jumlah persentase nilai belum tuntas peserta didik lebih besar dari pada tingkat ketuntasan peserta didik. Hal ini dapat dilihat dari jumlah peserta didik yang memperoleh nilai 65 ke atas hanya sebanyak 27 peserta didik (39\%), sedangkan jumlah peserta didik yang memperoleh nilai dibawah 65 sebanyak 42 peserta didik (61\%). Berdasarkan standar KKM mata pelajaran IPS yaitu 65, maka peserta didik Kelas IV MIN 2 Bandar Lampung lebih banyak yang memiliki nilai yang tidak sesuai standar KKM dibandingkan dengan peserta didik yang telah memenuhi standar KKM.

Dalam proses pembelajaran sering terjadi salah pemahaman antara guru dan peserta didik terhadap materi yang disampaikan oleh guru yang disebabkan oleh penguasaan materi awal peserta didik yang tidak terbentuk sejak proses KBM dimulai. Bahkan sebagian dari mereka belum mengetahui materi apa yang akan dipelajari pada saat itu, mereka melaksanakan proses pembelajaran tanpa adanya kesiapan berupa pengetahuan dasar. Mereka hanya duduk, mendengarkan, dan menjawab pertanyaan semampu mereka tanpa mengetahui alur pembahasan yang dijelaskan oleh guru. Padahal, penguasaan konsep awal materi sangat dibutuhkan untuk mengarahkan peserta didik pada pembahasan materi selanjutnya. Selain itu, jika siswa memiliki konsep materi lebih awal, pembelajaran menjadi terarah dan peserta didik menjadi paham materi yang akan disampaikan oleh guru. Kondisi kelas yang kurang kondusif semakin mempersulit tujuan pembelajaran dalam menciptakan komunikasi dua arah antara peserta didik dan guru. Guru harus melakukan diagnosis terhadap kondisi awal peserta didik, apakah peserta didik sudah membaca buku yang berisi materi yang akan dibahas dan apakah peserta didik memahami tentang materi yang akan dijelaskan (Djamarah, 2008: 109).

Berdasarkan data di atas, maka perlu diterapkan metode pembelajaran yang bernilai edukatif dan inovatif agar dapat membuat peserta didik untuk tertarik mengikuti proses pembelajaran di kelas. Banyak metode pembelajaran yang dapat 
diterapkan guru dalam upaya memperbaiki kualitas pembelajaran IPS. Salah satu bentuk metode pembelajaran tersebut adalah dengan metode Learning Start With a Question (LSQ).

\section{B. LANDASAN TEORI}

\section{Metode Learning Starts With A Question (LSQ)}

Susanto (2013: 432) berpendapat, "metode Learning Starts With a Question adalah metode dimana siswa diarahkan untuk belajar mandiri dengan membuat pertanyaan berdasarkan bacaan yang diberikan oleh guru". Metode Learning Start With a Question (LSQ) adalah suatu metode pembelajaran aktif yang dimulai dengan bertanya kemudian pendidik menjelaskan apa yang ditanyakan peserta didik. Menurut Silberman (2012: 156) metode Learning Start With A Question ( $L S Q$ ) adalah metode pembelajaran aktif melalui bertanya. Proses mempelajari sesuatu lebih efektif jika siswa aktif, mencari pola dari pada menerima saja. Salah satu cara menciptakan pola belajar aktif adalah dengan merangsang siswa untuk bertanya tanpa penjelasan terlebih dahulu.

Jadi metode Learning Start With A Question (LSQ) adalah metode pembelajaran yang digunakan untuk meningkatkan keaktifan siswa dalam pembelajaran di kelas. Keaktifan siswa dalam proses pembelajaran akan menciptakan situasi belajar aktif. Belajar aktif sangat diperlukan siswa untuk memperoleh hasil belajar yang maksimal.

Langkah-langkah penerapan metode pembelajaran Learning Starts With A Question (LSQ) yaitu (Supridjono, 2009: 112):

a. Pilih bacaan yang sesuai kemudian bagikan kepada siswa. Dengan cara memilih satu topik atau bab tertentu dari buku teks. Usahakan bacaan itu bacaan yang memuat informasi umum atau bacaan yang memberi peluang ntuk ditafsirkan berbeda-beda.

b. Mintalah kepada siswa untuk mempelajari bacaan secara sendiri atau dengan teman.

c. Mintalah kepada siswa untuk memberi tanda pada bagian bacaan yang tidak dipahami. Anjurkan kepada mereka untuk member tanda sebanyak mungkin. Jika waktu memungkinkan, gabungkan pasangan belajar dengan pasangan

Pengaruh metode pembelajaran learning start with a question (lsq) terhadap hasil belajar ips kelas iv min 2 bandar lampung tahun pelajaran 2017/2018 
yang lain, kemudian minta mereka untuk membahas poin-poin yang tidak diketahui yang telah diberi tanda.

d. Di dalam pasangan atau kelompok kecil, minta kepada siswa untuk menuliskan pertanyaan tentang materi yang telah mereka baca.

e. Kumpulkan pertanyaan-pertanyaan yang telah ditulis oleh siswa.

f. Sampaikan materi pelajaran dengan menjawab pertanyaan- pertanyaan tersebut.

\section{Hasil Belajar}

Hasil belajar adalah perubahan prilaku yang berupa pengetahuan atau pemahaman, keterampilan, dan sikap yang diperoleh peserta didik selama berlangsungnya proses belajar mengajar atau yang lazim disebut dengan pembelajaran. Hasil belajar mempunyai peranan penting dalam proses pembelajaran (Susanto, 2014: 1). Sudjana (2001: 22) mengatakan,’hasil belajar adalah kemampuan-kemampuan yang dimiliki siswa setelah ia menerima pengalaman belajarnya." Hasil belajar yang dimaksud dapat berupa pemahaman siswa mengenai pelajaran yang telah diberikan, atau dapat berupa analisis terhadap suatu hal, dan dapat pula dalam bentuk pemecahan masalah yang dilakukan oleh siswa terhadap suatu hal tertentu.

Dari pendapat di atas, dapat disimpulkan bahwa hasil belajar merupakan bukti pencapaian kemampuan belajar yang diperoleh siswa setelah melalui serangkaian kegiatan pembelajaran, yang bertujuan untuk mengukur ketercapaian tujuan pembelajaran yang telah ditentukan.

Menurut Bloom dalam hasil belajar terbagi menjadi tiga ranah yaitu:

a. Ranah Kognitif, yaitu berkenaan dengan hasil belajar intelektual yang terdiri dari enam aspek yaitu pengetahuan, ingatan, pemahaman, aplikasi, analisis, sintesis, dan evaluasi;

b. Ranah Afektif, yaitu berkenaan dengan sikap yang terdiri dari lima spek, yakni penerimaan, jawaban atau reaksi, penelitian, organisasi, dan internalisasi;

c. Ranah Psikomotorik, yaitu berkenaan dengan hasil belajar ketrampilan dan kemampuan bertindak. Ada enam aspek ranah psikomotorik, yakni gerakan refleks, keterampilan gerakan dasar, kemampuan perceptual, keharmonisan 
atau ketepatan, gerakan keterampilan kompleks, dan gerakan ekspresif dan interpretatif (Sudjana, 2001: 22-23).

Tiga ranah yang dikemukakan diatas yaitu ranah kognitif, ranah afektif, dan ranah psikomotorik merupakan ranah yang dapat dilakukan oleh siswa. Ketiga ranah tersebut dapat diperoleh siswa melalui kegiatan belajar mengajar. Pada penelitian ini yang diukur adalah ranah kognitif saja karena berkaitan dengan kemampuan para siswa dalam menguasai materi pelajaran.

\section{Ilmu Pengetahuan Sosial}

Ilmu Pengetahuan Sosial merupakan mata pelajaran yang mengkaji seperangkat peristiwa, fakta, konsep, dan generalisasi yang berkaitan dengan isu sosial dan kewarganegaraan (Fajar, 2002: 110).

Ilmu Pengetahuan Sosial (IPS) merupakan integrasi dari berbagai cabang ilmu-ilmu sosial seperti: sosiologi, sejarah, geografi, ekonomi, politik, hukum dan budaya. IPS juga dirumuskan atas dasar realita dan fenomena sosial yang mewujudkan satu pendekatan interdisipliner dari aspek dan cabang-cabang ilmu-ilmu sosial (Trianto, 2007: 171).

Jadi IPS adalah mata pelajaran yang mempelajari kehidupan sosial. Dan IPS juga membahas hubungan antara manusia dengan lingkungannya. Lingkungan masyarakat dimana peserta didik tumbuh dan berkembang sebagai bagian dari masyarakat, dihadapkan pada berbagai permasalahan yang ada dan terjadi di lingkungan sekitar. Pembelajaran IPS membantu peserta didik dalam memecahkan permasalahan yang dihadapi sehingga akan menjadikannya semakin mengerti dan memahami lingkungan sosial masyarakatnya.

Ruang lingkup mata pelajaran IPS meliputi aspek-aspek sebagai berikut (Fajar, 2002: 111).
a. Manusia, Tempat, dan Lingkungan
b. Waktu, Keberlanjutan, dan Perubahan
c. Sistem Sosial dan Budaya
d. Perilaku Ekonomi dan Kesejahteraan.

\section{METODE PENELITIAN}

Penelitian ini termasuk kedalam jenis kuantitatif. Metode penelitian yang digunakan adalah Quasy Experimental Design dengan desain dalam penelitian ini 
adalah Nonequivalent Control Group Design. Populasi dalam penelitian ini adalah kelas IV A, IV B, IV C MIN 2 Bandar Lampung, Tahun Ajaran 2017/2018 sejumlah 3 kelas. Teknik pengambilan sampel yang digunakan dalam penelitian ini adalah purposive sampling. Dalam penelitian ini yang terpilih sebagai kelas eksperimen adalah kelas IV A yang berjumlah 34 siswa, sedangkan kelas yang terpilih sebagai kelas kontrol adalah kelas IV B dengan jumlah 35 siswa.

Metode pengumpulan data menggunakan tes dan dokumentasi. Instrumen yang dikembangkan dalam penelitian ini adalah tes, yang akan digunakan untuk mengukur hasil belajar IPS siswa yang berupa tes pencapaian (achievement test) terdiri dari tes obyektif bentuk pilihan ganda sebanyak 40 soal dan daftar dokumentasi.

Analisis uji coba instrument dalam penelitian ini yaitu: uji validitas, uji tingkat kesukaran, uji daya beda, dan uji reliabilitas. Sedangkan uji analisis datanya menggunakan uji normalitas dan homogenitas. Untuk menguji hipotesis dilakukan dengan menggunakan uji kesamaan dua rata-rata atau uji pihak kanan yaitu uji t. menggunakan uji t karena yang dibandingkan adalah dua rata-rata dan dua hal yang benar-benar berbeda. Uji t dilakukan dengan cara uji kesamaan dua varian dilakukan pada data post-test kelompok eksperimen dan kontrol. Uji ini bertujuan untuk mengetahui apakah kedua kelompok memiliki varian yang sama atau tidak. Setelah kedua sampel sama atau berbeda (homogen). Uji ini dilakuakan dengan SPSS dapat di lihat di independent samples test uji ini dilakukan dengan membandingkan nilai $t_{\text {hitung }}$ dengan nilai $t_{\text {tabel. }}$ Uji ini dilakukan menggunakan uji $\mathrm{t}_{\text {test }}$ dua sisi yang dapat dirumuskan sebagai berikut:

\section{Menentukan Hipotesis}

$\mathrm{H}_{\mathrm{O}}$ : Metode learning start with a question tidak berpengaruh secara positif dan signifikan terhadap hasil belajar peserta.

$\mathrm{Ha}$ : Metode learning start with a question berpengaruh secara positif dan signifikan terhadap hasil belajar peserta

Pengaruh metode pembelajaran learning start with a question (lsq) terhadap hasil belajar ips kelas iv min 2 bandar lampung tahun pelajaran 2017/2018 


\section{Menentukan Dasar Pengambilan Keputusan}

e-ISSN 2580-8915

a. Berdasarkan t-hitung

1) Jika $t_{\text {hitung }} \geq r_{\text {tabel }}$ maka Ho ditolak dan Ha diterima, berarti Metode learning start with a question berpengaruh secara positif dan signifikan terhadap hasil belajar.

2) Jika $t_{\text {hitung }} \leq r_{\text {tabel }}$ maka Ho diterima dan Ha ditolak, berarti Metode learning start with a question tidak berpengaruh secara positif dan signifikan terhadap hasil belajar.

b. Berdasarkan sig.(2-tailed)

1) Jika nilai probabilitas $(0,05) \leq$ nilai probability sig atau $(0,05 \leq \operatorname{sig})$, maka Ho diterima dan Ha di tolak artinya tidak signifikan.

2) Jika nilai probabilitas $(0,05) \geq$ nilai probability sig atau $(0,05 \leq \mathrm{sig})$, maka Ho diterima dan Ha di tolak artinya signifikan (Budiono, 2009: 142-145).

\section{HASIL PENELITIAN}

\section{Uji Prasyarat Analisis}

a. Uji validitas

Dalam penelitian ini butir soal dinyatakan valid jika nilai Corrected ItemTotal Correlation yang di peroleh lebih besar atau sama dengan 0,396. Nilai 0,396 dihitung dengan melihat tabel distribusi nilai $\mathrm{r}_{\text {tabel }}$ dengan signifikansi $5 \%$. Diketahui dengan $\mathrm{N}-2=25-2=23$ pada taraf signifikan $5 \%$, nilai $\mathrm{r}_{\text {tabel }}$ diperoleh sebesar 0,396. $\mathrm{N}=25$ karena jumlah siswa sebanyak 25 orang anak. Hasil output perhitungan validitas dengan bantuan program komputer IBM SPSS Statistics v.20 for Windows teknik Corrected Item-Total Correlation.

Berdasarkan uji validitas yang telah dilakukan, maka diketahui ada 23 item soal yang valid yaitu item soal nomor 2, 4, 5, 6, 7, 8, 10, 11, 13, 17, 18, 21, 22, 23, $26,27,28,30,31,33,34,35$ dan item soal yang tidak valid yakni 1, 3, 9, 14, 15, $16,19,20,24,25,29,32,36,37,38,39,40$ soal nomor sehingga pada item yang tidak valid di drop / di buang.

Pengaruh metode pembelajaran learning start with a question (lsq) terhadap hasil belajar ips kelas iv min 2 bandar lampung tahun pelajaran 2017/2018 
b. Uji tingkat kesukaran

Taraf kesukaran soal adalah proporsi (P) peserta tes yang menjawab benar terhadap butir soal tersebut. Dalam menentukan indeks kesukaran butir soal antara 0.00-1.00, dengan klasifikasi sebagai berikut :

1) Jika nilai $\mathrm{P}<0.30$, maka butir soal termasuk kategori soal yang derajat kesukarannya tergolong sukar.

2) Jika nilai $0.30<\mathrm{P}<0.70$, maka butir soal termasuk kategori soal yang derajat kesukarannya tergolong sedang/cukup.

3) Jika nilai $\mathrm{P}>0.70$, maka butir soal termasuk kategori soal yang derajat kesukarannya tergolong mudah.

Berdasarkan hasil uji taraf kesukaran butir soal yang telah dilakukan, diketahui bahwa 40 butir soal memiliki derajat kesukaran antara lain pada nomor $9,12,14,15,16,21,36,37,38,39,40$ yang tergolong mudah. Selanjutnya pada nomor soal $1,2,3,4,5,6,7,8,10,11,13,17,18,19,20,22,23,24,25,26,27$, $28,29,30,31,32,33,34,35$ yang tergolong sedang.

c. Uji daya beda

Proses pengolahan data daya pembeda soal menggunakan program komputer IBM SPSS Statistics v.20 for Windows. Berdasarkan hasil uji daya pembeda butir soal yang telah dilakukan, diketahui bahwa 40 butir soal memiliki daya pembeda antara lain pada nomor 1, 14, 19, 24, 32, 36, 37, 38, 40 yang tergolong jelek. Selanjutnya pada nomor soal 15, 18, 20, 25, 29, 39 yang tergolong cukup dan yang termasuk dalam kategori daya pembeda yang tergolong baik adalah butir soal nomor 2, 3, 4, 5, 6, 7, 8, 9, 10, 11, 12, 13, 17, 21, 22, 23, 26, $27,28,30,31,33,34,35$.

d. Uji reliabilitas

Hasil uji reliabilitas dilakukan dengan bantuan IBM SPSS Statistics v.20 for Windows diperoleh koefisien Croanbach's Alpha sebesar $\alpha=0,878$. Berdasarkan klasifikasi reliabilitas soal diatas artinya derajat keterandalan instrumen berada pada kategori sangat tinggi. Dengan demikian, instrumen yang digunakan sudah baik dan dipercaya sebagai alat pengumpulan data, sehingga kegiatan penelitian dapat dilanjutkan pada proses selanjutnya.

Pengaruh metode pembelajaran learning start with a question (Isq) terhadap hasil belajar ips kelas iv min 2 bandar lampung tahun pelajaran 2017/2018 


\section{Analisis data}

e-ISSN 2580-8915

a. Uji normalitas

Untuk mengetahui sebaran data hasil belajar IPS pretest dan posttest tersebut berdistribusi normal atau tidak, maka dilakukan uji normalitas Kolmogorov-Smirnov dengang menggunakan IBM SPSS Statistics v.20 for windows dapat dilihat pada tabel sebagai berikut:

Tabel 1.

Rekapitulasi Uji Normalitas Data Pretest dan Posttest Hasil Belajar IPS Kelas Eksperimen dan Kontrol

\begin{tabular}{|c|c|c|c|c|}
\hline No. & Data & Sig. (2-tailed) & $\boldsymbol{\alpha ~ ( 5 \% )}$ & Keterangan \\
\hline 1 & Pretest & 0,587 & 0,05 & Normal \\
\hline 2 & Posttest & 0,446 & 0.05 & Normal \\
\hline
\end{tabular}

Dari tabel pretest dijelaskan bahwa data berdistribusi nomal yang dapat dilihat dari nilai signifikasi atau probabilitasnya. Pedoman pengambilan keputusannya adalah apabila nilai signifikansi $<0,05$ maka data tidak normal dan sebaliknya, jika nilai signifikansi > 0,05 maka data dinyatakan normal. Nilai probabilitas atas nilai sig yang didapat dari data soal tes hasil belajar IPS yaitu $0,587>0,05$ maka data-data tersebut berdistribusi normal.

Dari tabel posttest dijelaskan bahwa data berdistribusi nomal yang dapat dilihat dari nilai signifikasi atau probabilitasnya. Pedoman pengambilan keputusannya adalah apabila nilai signifikansi $<0,05$ maka data tidak normal dan sebaliknya, jika nilai signifikansi > 0,05 maka data dinyatakan normal. Nilai probabilitas atas nilai sig yang didapat dari data soal tes hasil belajar IPS yaitu $0,446>0,05$ maka data-data tersebut berdistrribusi normal.

b. Uji homogenitas

Uji homogenitas digunakan untuk mengetahui apakah kedua skala ukur memiliki karakter yang sama atau tidak. Uji homogenitas Levene dilakukan pada data variabel terikat yaitu metode pembelajaran learning start with a question dan variabel bebas yaitu hasil belajar IPS dengan menggunakan IBM SPSS Statistics v.20 for windows.

Pengaruh metode pembelajaran learning start with a question (1sq) terhadap hasil belajar ips kelas iv min 2 bandar lampung tahun pelajaran 2017/2018 
Tabel 2.

\section{Rekapitulasi Uji Homogenitas Data Pretest dan Posttest Hasil Belajar IPS Kelas Eksperimen dan Kontrol}

\begin{tabular}{|c|c|c|c|c|}
\hline No. & Data & Sig. (2-tailed) & $\boldsymbol{\alpha}(\mathbf{5 \%})$ & Keterangan \\
\hline 1 & Pretest & 0,782 & 0,05 & Homogen \\
\hline 2 & Posttest & 0,246 & 0.05 & Homogen \\
\hline
\end{tabular}

Dari tabel pretest dijelaskan bahwa data berdistribusi nomal yang dapat dilihat dari nilai signifikasi atau probabilitasnya. Pedoman pengambilan keputusannya adalah apabila nilai signikansi $<0,05$ maka data tidak homogen dan sebaliknya, jika nilai signifikansi > 0,05 maka data dinyatakan homogen. Nilai probabilitas atas nilai sig yang didapat dari data soal tes hasil belajar IPS yaitu $0.782>0,05$ maka data-data tersebut persebarannya homogen.

Dari tabel posttest dijelaskan bahwa data berdistribusi nomal yang dapat dilihat dari nilai signifikasi atau probabilitasnya. Pedoman pengambilan keputusannya adalah apabila nilai signikansi $<0,05$ maka data tidak homogen dan sebaliknya, jika nilai signifikansi > 0,05 maka data dinyatakan homogen. Nilai probabilitas atas nilai sig yang didapat dari data soal tes hasil belajar IPS yaitu $0,246>0,05$ maka data-data tersebut persebarannya homogen.

c. Uji hipotesis Uji-t Independent

Tabel 3.

Hasil Uji Independent T-test Posttest Hasil Belajar IPS

Independent Samples Test

\begin{tabular}{|c|c|c|c|c|c|c|c|c|c|c|}
\hline & \multicolumn{2}{|c|}{$\begin{array}{c}\text { Levene's Test for } \\
\text { Equality of Variances }\end{array}$} & \multicolumn{7}{|c|}{ t-test for Equality of Means } \\
\hline & & \multirow[t]{2}{*}{$\bar{F}$} & \multirow[t]{2}{*}{ Sig. } & \multirow[t]{2}{*}{$\mathrm{t}$} & \multirow[t]{2}{*}{$\mathrm{df}$} & \multirow[t]{2}{*}{$\begin{array}{l}\text { Sig. }(2- \\
\text { tailed) }\end{array}$} & \multirow[t]{2}{*}{$\begin{array}{c}\text { Mean } \\
\text { Difference }\end{array}$} & \multirow[t]{2}{*}{$\begin{array}{c}\text { Std. Error } \\
\text { Difference }\end{array}$} & \multicolumn{2}{|c|}{$\begin{array}{l}\text { 95\% Confidence } \\
\text { Interval of the } \\
\text { Difference }\end{array}$} \\
\hline & & & & & & & & & Lower & Upper \\
\hline $\begin{array}{l}\text { Hasil } \\
\text { belajar } \\
\text { ips }\end{array}$ & $\begin{array}{l}\text { Equal variances } \\
\text { assumed } \\
\text { Equal variances not } \\
\text { assumed }\end{array}$ & 1.370 & .246 & $\begin{array}{l}3.618 \\
3.627\end{array}$ & $\begin{array}{r}67 \\
65.800\end{array}$ & $\begin{array}{l}.001 \\
.001\end{array}$ & $\begin{array}{l}5.78151 \\
5.78151\end{array}$ & $\begin{array}{l}1.59790 \\
1.59405\end{array}$ & $\begin{array}{l}2.59209 \\
2.59871\end{array}$ & 8.96431 \\
\hline
\end{tabular}

Pengaruh metode pembelajaran learning start with a question (1sq) terhadap hasil belajar ips kelas iv min 2 bandar lampung tahun pelajaran 2017/2018 
1) Menentukan hipotesis

Untuk menguji hipotesis ada pengaruh metode pembelajaran learning start with a question terhadap hasil belajar IPS siswa kelas IV MIN 2 Bandar Lampung dimana :

$\mathrm{H}_{\mathrm{a}}=$ "Ada (terdapat) pengaruh yang signifikan metode pembelajaran learning start with a question terhadap hasil belajar IPS"

$\mathrm{H}_{\mathrm{o}}=$ "Tidak ada (tidak terdapat) pengaruh yang signifikan metode pembelajaran learning start with a question terhadap hasil belajar IPS."

2) Menentukan dasar pengambilan keputusan

a) Berdasarkan sig.(2-tailed)

Jika nilai sig. $(2$-tailed) $<0.05$, maka Ha diterima

Jika nilai sig.(2-tailed) > 0.05, maka Ha ditolak

Berdasarkan nilai sig.(2-tailed) yang diperoleh yaitu 0.001, berarti : $0.001<$ 0.05 maka Ha diterima.

b) Berdasarkan t-hitung

Jika nilai t-hitung > t-tabel, maka Ha diterima

Jika nilai t-hitung < t-tabel, maka Ha ditolak

Berdasarkan perhitungan, diketahui t-tabel : df ( 67-2 =65 ) pada taraf 5\% (0.05) sebesar 1,997, berarti : t-tabel $=1,997<\mathrm{t}$-hitung $=3.627$ maka Ha diterima.

\section{E. PEMBAHASAN}

Penelitian ini bertujuan untuk mengetahui pengaruh metode pembelajaran learning start with a question terhadap hasil belajar IPS siswa di kelas IV MIN 2 Bandar Lampung Tahun Ajaran 2017/2018. Jumlah sampel dalam penelitian ini ialah sebanyak 69 siswa dengan rincian 34 siswa di kelas IV A dan 35 siswa di kelas IV B, teknik sampling yang digunakan adalah teknik purposive sampling dengan hasil kelas kelas IV A sebagai kelas eksperimen dan kelas IV B sebagai kelas kontrol. Dari tes uji instrumen tersebut diperoleh data hasil tes instrumen butir soal hasil belajar IPS adalah 20 butir soal valid untuk masing-masing pretest dan posttest. Berdasarkan hasil penghitungan dihasilkan bahwa rata-rata pretest kelompok Eksperimen 56,02 dengan jumlah responden 34 siswa. Sedangkan pada 
kelas kontrol memiliki rata-rata 53,00 dengan jumlah responden 35 siswa dan jelas terlihat bahwa tidak adanya perbedaan yang signifikan sebelum diberikan treatmen/perlakuan. Selanjutnya setelah diberi treatmen/perlakuan pada kelas eksperimen dan kelas kontrol maka diperoleh nilai posttest dengan rata-rata 72,35 pada kelas eksperimen dan 66,57 pada kelas kontrol.

Hasil penelitian menunjukkan bahwa hasil belajar siswa pada mata pelajaran IPS menggunakan metode pembelajaran Learning start with a question lebih tinggi dari pada hasil belajar pada mata pelajaran IPS dengan menggunakan metode pembelajaran information search. Hal ini sesuai dengan perhitungan program IBM SPSS Statistics v.20 for windows yang menggunakan analisis Uji $t$ untuk sampel yang berasal dari distribusi yang berbeda Independent samples test. Hasil perhitungan data menunjukkan bahwa nilai Sig $=0,001$ atau t-tabel $=1,997$ $<\mathrm{t}$-hitung $=3.627$. Ini berarti nilai thitung lebih besar dari nilai t $t a b e l$ baik pada taraf 5\%. Maka hipotesis nihil (Ho) ditolak dan hipotesis alternatif (Ha) diterima, sehingga dapat disimpulkan bahwa terdapat pengaruh yang signifikan pada penerapan metode pembelajaran learning start with a question terhadap hasil belajar IPS siswa di kelas IV MIN 2 Bandar Lampung.

Penelitian ini juga menunjukkan terdapat perbedaan keaktifan belajar peserta didik secara signifikan antara peserta didik kelas IV yang memperoleh pembelajaran menggunakan metode pembelajaran menggunakan metode pembelajaran learning start with a question dan terdapat perbedaan peningkatan hasil belajar secara signifikan antara siswa kelas IV yang memperoleh pembelajaran menggunakan metode pembelajaran learning start with a question. Selain itu motivasi belajar peserta didik yang diajar mengunakan metode Learning starts with a question juga lebih baik dari pada yang diajar mengunakan metode konvensional.

Berdasarkan hasil pembelajaran yang dilakukan peneliti terhadap siswa selama proses pembelajaran berlangsung menunjukkan perbedaan yaitu: semua siswa mengikuti kegiatan belajar mengajar dengan sungguh-sungguh, semua siswa membentuk kelompok sesuai dengan intruksi guru, siswa bertanggung jawab dalam kegiatan kelompok, semua siswa membaca materi yang diberikan guru, siswa membuat pertanyaan secara kelompok, dalam kegiatan kelompok 
mereka menjadi aktif bertanya. Hal ini sangat relevan dengan tujuan metode pembelajaran learning start with a question yaitu agar peserta didik dapat mengembangkan minat dan motivasi siswa untuk aktif dalam belajar, menilai kesiapan siswa, mengembangkan keterampilan berpikir kritis, dan mengingat pengetahuan sebelumnya.

Perbedaan keaktifan siswa terjadi karena pembelajaran melalui metode pembelajaran learning start with a question sangat menarik bagi siswa. Siswa lebih tertarik dengan metode pembelajaran ini karena memberikan kesempatan bagi siswa untuk lebih aktif bertanya dalam pembelajaran.

Metode pembelajaran learning start with a question juga mempunyai kelemahan, diantaranya: tidak selamanya mudah bagi siswa untuk membuat pertanyaan yang menyebabkan siswa yang kurang pandai akan kebingungan, lebih sedikit ide yang masuk, suasana kelas menjadi ribut karna semua siswa berdiskusi tentang materi yang dibagikan, selain itu pembicaraan hanya dimonopoli oleh siswa yang terbiasa dan terampil mengemukakan pendapat. Dalam hal ini yang dibutuhkan adalah kreativitas dan kepekaan guru sangatlah penting untuk dikembangkan.

Selain itu, kreativitas guru juga dapat membuat proses pembelajaran lebih menyenangkan. Jika dibandingkan dengan kelas kontrol yang menggunakan metode pembelajaran information search dengan metode ini anak-anak cenderung pasif, fasilitas kurang memadai, sulit dipahami peserta didik metode pembelajaran yang peneliti berikan. Maka dari itu, jika para pendidik mau berusaha keluar dari cara pengajaran yang berpusat pada guru dan mau berpikir kreatif sehingga dapat mencapai tujuan pembelajaran yang diharapkan.

Penerapan metode pembelajaran learning start with a question berpengaruh terhadap hasil belajar IPS siswa kelas IV, terdapat perbedaan hasil belajar IPS antara peserta didik yang diajar dengan menggunakan metode pembelajaran learning start with a question dengan peserta didik yang diajar melalui metode pembelajaran information search. Sehingga dapat disimpulkan bahwa terdapat pengaruh yang signifikan siswa di kelas IV MIN 2 Bandar Lampung Tahun Pelajaran 2017/2018.

Pengaruh metode pembelajaran learning start with a question (lsq) terhadap hasil belajar ips kelas iv min 2 bandar lampung tahun pelajaran 2017/2018 


\section{F. KESIMPULAN}

e-ISSN 2580-8915

Terdapat Pengaruh Metode Pembelajaran Learning Start With A Question (LSQ) Terhadap Hasil Belajar IPS Kelas IV MIN 2 Bandar Lampung. Berdasarkan hasil pengujian hipotesis yang menggunakan Independen t-test diperoleh $t_{\text {hitung }}$ lebih besar dari $t_{\text {tabel }}(3,627>1,997)$, dengan taraf segnifikan kurang dari $5 \%(0,001<0,05)$.

\section{G. DAFTAR PUSTAKA}

Agus Suprijono. 2009. Cooperatif Learning Teori dan aplikasi PAIKEM. Pustaka Pelajar. Yogyakarta.

Ahmad Susanto. 2014. Pengembangan Pembelajaran IPS Di sekolah Dasar. Prenada media group. Jakarta.

Arnie Fajar. 2002. Portofolio Dalam Pelajaran IPS. Remaja Rosdakarya. Bandung.

Budiono. 2009. Statistik untuk Penelitian. UNS Press. Surakarta.

Melvin L. Silberman. 2012. Active Learning: 101 Cara Belajar Siswa Aktif. Nuansa. Bandung.

Nana Sudjana. 2001. Penilaian Hasil Proses Belajar Mengajar. Remaja Rosdakarya. Bandung.

Suryo Budi Susanto. Pengaruh Metode Learning Starts With A Question Terhadap Hasil Belajar Siswa Pada Standar Kompetensi Memahami Sifat Dasar Sinyal Audio di SMK Negeri 2 Surabaya. Jurnal Pendidikan Teknik Elektro. No. 1. Tahun 2013.

Syaiful Bahri Djamarah. 2008. Psikologi Belajar. Rineka cipta. Jakarta.

Trianto. 2007. Model Pembelajaran Terpadu. Prestasi Pustaka. Jakarta.

Pengaruh metode pembelajaran learning start with a question (lsq) terhadap hasil belajar ips kelas iv min 2 bandar lampung tahun pelajaran 2017/2018 